\begin{tabular}{|c|c|c|}
\hline & Int.J.Curr.Microbiol.App.Sci (2021) 10(12): 404-415 & \\
\hline & $\begin{array}{l}\text { International Journal of Current Microbiology and Applied Sciences } \\
\text { ISSN: 2319-7706 Volume } \mathbf{1 0} \text { Number } \mathbf{1 2} \mathbf{( 2 0 2 1 )} \\
\text { Journal homepage: } \underline{\text { http://www.ijcmas.com }}\end{array}$ & 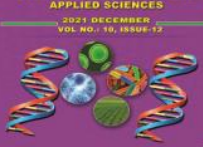 \\
\hline $\begin{array}{l}\text { EXCELLENT } \\
\text { PUBLISHERS }\end{array}$ & & \\
\hline
\end{tabular}

\title{
Decentralized Agricultural Planning in Kerala-Process and Determinants of Efficacy
}

\author{
P. K. Abdul Jabbar* and Jiju P. Alex \\ Department of Agricultural Extension, College of Agriculture, Kerala Agricultural university, \\ Thrissur- 686656, India \\ *Corresponding author
}

\section{A B S T R A C T}

\section{Keywords}

Decentralization, Agricultural planning, Efficacy determinants, Institutionalization

\section{Article Info}

Received: 05 November 2021 Accepted: 04 December 2021 Available Online: 10 December 2021
The long-drawn process of institutionalization of decentralized planning in Kerala has impacted grass root level agricultural development in several ways. The regular interactions of officials and farmers in the process significantly have influenced service delivery to the public forming innovative solutions, fruitful experiences and institutional learnings. But there is an urgent need to scale up farmer participation in the process by enhancing efficacy of the process of institutionalisation. Delineation of the determinants of the efficacy of decentralised agricultural planning at grass root level in Kerala is of utmost importance to address various dimensions of the institutionalisation process lagging behind and to enhance efficacy. It was done based on a set of dimensions selected through literature review and expert rating. Among various steps, integration of projects, finalisation of annual plan by the local governments, formation of panchayath planning committee, consolidation of local plans to district plans and prioritisation and resource allocation by local bodies received low perceived efficacy scores. The factor analysis of the data delineated development-participation inter dependence, group decision making \& performance, experience -accountability capabilities, and knowledge mediationas four factors explaining maximum variance in the perceived efficacy of institutionalization of decentralized planning in agriculture in Kerala.

\section{Introduction}

Kerala has successfully evolved a paradigm of decentralized and participatory development planning by utilizing the provisions of the $73^{\text {rd }}$ and $74^{\text {th }}$ amendments of the constitution. Initiated as the Peoples' Plan Campaign in the ninth five year plan led by the Local Self Government Institutions, this process has undergone several changes during the last two decades. The conscientization phase of the campaign which was intended to educate the bureaucracy, political leadership and the people about the dynamics and structure of participatory planning gave way to institutionalization of the process during the $10^{\text {th }}$ plan period, which rechristened the programme as 'Kerala Development Plan' 
(KDP). Subsequently, during the $11^{\text {th }}$ plan, the planning mechanism was further revamped to consolidate the institutionalization process. The approach of the 12th plan also envisaged some concrete steps to strengthen the institutions as well as the planning procedures based on previous experiences. The $13^{\text {th }}$ plan adopted a watershed based approach to address problems related to agriculture, drinking water, and management of natural resources and formulation of district plans (GoK, 2017).

\section{Institutionalisation and participation}

The long-drawn process of institutionalization of decentralized planning has impacted grassroots level planning for agricultural development in the state in several ways. Heller et al., (2007) observed that 'People's Plan Campaign' for decentralized planning in Kerala had increased the level of participation of people and had created a positive impact on development performance and on social inclusion, but that level of participation have declined in recent years. Vijayanand (2010) while analyzing the participatory planning experiences in Kerala pointed out the local passivity that had crept into the process and the need to revamp the procedures to make planning more participatory. He further observed that participation of the people would take place only when there were efficient democratic structures for facilitating participation.

The regular interactions of officials and farmers in the gramasabha significantly have influenced service delivery to the public and formed innovative solutions fruitful experiences and institutional learnings (Alex and Sulaja, 2012). But there are observations to strengthen the collective planning space at grass root level by debureaucratizing (Harilal, 2012). Many constraints limit participation and performance of agricultural working group members in participatory planning (Jabbar and Sundaramari, 2014). Inherent methodological problems in the processes have to resolved for better coordination and peoples participation (Mohanan and Prakash, 2016). Benefits of decentralization will be trickling down to lower sections of society only when the innovation platform gets institutionalized (Dominic and Gupta, 2019).

But many determinants like Social participation, extension participation and role performance can inculcate a favourable attitude towards panchayat raj institutions (Srivastava et al., 2021).

\section{Materials and Methods}

\section{Study area}

The study was conducted in five agroclimatic zones of Kerala. Five districts selected for study were Thiruvananthapuram (Northern Kerala), Palakkad (central zone), Malappuram (Northern Kerala), Wayanad (High range zone) and Thrissur (Problem Area Zone). Forty panchayats were selected based on cropping intensity. A brief profile of the study area has been given in Table. 1

\section{Study sample}

Stratified random sampling procedure was followed for the purpose of drawing sample for the study. One district each was randomly selected from each of the five agro climatic zones of Kerala.

From each district eight Panchayaths with high cropping intensity were selected. The sample of respondents comprised of 40 Agricultural Officers, 40 Grama Panchayat Presidents and 80 farmers who are members of the agricultural working group at Panchayat level constituted for participatory planning. The total sample size thus was 160 . 
Measurement of efficacy of decentralized agricultural planning and determinants

The decentralised Agricultural Planning through Local Self Government Institutions LSGIs of Kerala has been institutionalised through a process involving 15 stages. 15 stages were further categorised in to three distinct phases - Participatory Need assessment phase, Plan formulation and resource allocation phase and Plan appraisal, Integration and implementation phase. After close scrutiny of various guidelines and orders of the LSGI and State Planning Board, perusing the past research studies and relevant literature in the area of participatory planning and by discussing with the agricultural scientists 120 parameters determining the efficacy of various stages were arrived at. These parameters were subjected to expert rating and a final 60 parameters were selected under 15 dimensions with four parameters under each dimension. Each parameter was judged based on the degree of efficacy of that parameter against a five-point continuum of mostly adopted, often adopted, occasionally adopted, rarely adopted and not adopted with scores 5, 4, 3, 2 and 1 respectively. Pretesting was done in a non-sampling area among 30 randomly selected respondents. The selected items were combined in to a scale. Then it was subjected content validity method through judges rating for the questionnaire validity. The reliability was found out using Cronbach's Alpha statistics and the value of 0.819 showed high reliability acceptable enough to be used in data collection. Other independent variables were measured adopting methodologies already standardised.

\section{Analysis of data}

Data collected was subjected to factor analysis to delineate factors determining perceived efficacy of decentralized agricultural planning process. Analysis was conducted using SPSS software for windows version 9.2. Using Principal component analysis, dimensionality of data was reduced to a few variables. Descriptive statistics like frequency and percentages were used to study the profiles of the respondents.

\section{Results and Discussion}

\section{Profile characteristics of the working group members}

The distribution of the working group members with respect to various profile characteristics selected for the study have been given in Table.2. Efficacy of decentralized planning was the dependent variable of the study.

From the table it is clear that majority of working groups belonged to the medium category with respect to mass media exposure, leadership quality, social participation, sharing of responsibility, attitude towards Panchayati raj, leadership propensity, attitude towards Participatory Planning, extension Agency Contact, accountability in planning and implementation, transparency within the group, sense of empowerment, participation in working group and efficacy of decentralized planning. With regard to age $51.66 \%$ belonged the middle age group (35-50), 32.5\% (young) and $15.83 \%$ in the old age group.

With regard to farming experience, $44.16 \%$ had 6-10 years, $33.33 \%$ 11-25 years and 22.5 $\%$ above 25 years. While 59.16 belonged to marginal farmers category of land possession, $22.5 \%$ belonged to the category of small farmers, $16.66 \%$ to medium farmers and only $1.69 \%$ to big farmers category.

While $34.17 \%$ of the members belonged to college and above category, $33.33 . \%$ had higher secondary education and $32.5 \%$ high school education. 
Perceived Efficacy of Working group members on Decentralized Agricultural Planning through Local Self Government Institutions LSGIs

As already discussed in the methodology chapter, the perceived efficacy of the institutionalisation of participatory planning was analysed in five agro climatic zones of Kerala. The respondents were classified in to three categories viz. low, medium and high based on their PEDP values. The results are depicted in Table.2 and Fig.2.

It could be observed from the Table No.3. and Figure.2. that 75 per cent of the working group members were found to have medium level of perceived efficacy followed by low (17.5\%) and high (7.5\%). Hence majority of the respondents were found to have medium level of PEDP.

Perceived Efficacy of Dimensions of Decentralized Planning through LSGI

Perceived efficacy of the institutionalisation process, analysed by the actors of the process was the dependent variable of the study. The decentralised planning process at grass root level was conceived as a 15-stage process stipulated in the guidelines of the Government of Kerala which were further categorised in to three distinct phases as discussed in Table.4.

Table.1 Profile of the study area five districts - an overview

\begin{tabular}{|c|c|c|c|c|c|}
\hline Parameter & $\begin{array}{c}\text { Thiruvanatha } \\
\text { puram }\end{array}$ & Thrissur & Palakkad & Malappuram & Wayanad \\
\hline Area (sq Km) & 2192 & 3032 & 4480 & 3550 & 2131 \\
\hline Forest Cover (sq. Km) & 1304 & 1159 & 2084 & 1981 & 1580 \\
\hline $\begin{array}{c}\text { Population 2011 } \\
\text { (in Lakh) }\end{array}$ & 33.01 & 31.21 & 28.1 & 41.13 & 8.17 \\
\hline $\begin{array}{c}\text { Density } \\
\text { SC population as \% of } \\
\text { Total Population }\end{array}$ & 1508 & 1031 & 627 & 1157 & 384 \\
\hline $\begin{array}{c}\text { ST population as \% of } \\
\text { Total Population }\end{array}$ & 0.8 & 10.4 & 14.4 & 7.5 & 4.0 \\
\hline $\begin{array}{c}\text { Production of Rice in } \\
\text { Kerala (2019-20) in } \\
\text { Tonnes (Wetland) }\end{array}$ & 4541 & 76556 & 248199.0 & 28214 & 19513 \\
\hline $\begin{array}{c}\text { Net Area Irrigated } \\
\text { (2019-20) in ha }\end{array}$ & 7842 & 62227 & 86026 & 29528 & 12186 \\
\hline $\begin{array}{c}\text { No. of Registered } \\
\text { SSI/MSME 2019-20 }\end{array}$ & 1363 & 1594 & 1694 & 1177 & 264 \\
\hline $\begin{array}{c}\text { No of Grama } \\
\text { Panchayaths }\end{array}$ & 73 & 86 & 88 & 94 & 23 \\
\hline
\end{tabular}


Table.2 Profile characteristics of Agriculture Working Group Members of LSGIs in Decentralised Planning $\mathrm{N}=120$

\begin{tabular}{|c|c|c|c|c|c|}
\hline Sl.No. & Variable & Number & Percentage & Mean & $\begin{array}{l}\text { Standard } \\
\text { deviation }\end{array}$ \\
\hline \multirow[t]{4}{*}{1} & Age & & & & \\
\hline & Young up to 35 & 39 & 32.5 & & \\
\hline & Middle 35-50 & 62 & 51.66 & 1.83 & 0.678 \\
\hline & Old 50 and above & 19 & 15.83 & & \\
\hline \multirow[t]{5}{*}{2} & Experience in farming & & & & \\
\hline & up to 5 years & 0 & 0 & & \\
\hline & $6-10$ years & 53 & 44.16 & 2.78 & 0.791 \\
\hline & $11-25$ years & 40 & 33.33 & & \\
\hline & Above 25 years & 27 & 22.5 & & \\
\hline \multirow[t]{5}{*}{3} & Land size & & & & \\
\hline & Marginal farmers Up to 2.50 acres & 71 & 59.16 & & \\
\hline & Small farmers $2.51-5.00$ acres & 27 & 22.5 & 1.61 & 0.823 \\
\hline & Medium farmers $5.01-10.00$ acres & 20 & 16.66 & & \\
\hline & Big farmers More than 10.00 acres & 2 & 1.69 & & \\
\hline \multirow[t]{6}{*}{4} & Formal education & & & & \\
\hline & Literate & 0 & 0 & & \\
\hline & Primary & 0 & 0 & & \\
\hline & High School & 39 & 32.5 & 4.02 & 0.820 \\
\hline & Higher secondary & 40 & 33.33 & & \\
\hline & College and above & 41 & 34.17 & & \\
\hline \multirow[t]{4}{*}{5} & mass media exposure & & & & \\
\hline & low & 20 & 16.66 & & \\
\hline & Medium & 83 & 69.16 & 14.48 & 1.861 \\
\hline & high & 17 & 14.16 & & \\
\hline \multirow[t]{4}{*}{6} & Leadership quality & & & & \\
\hline & low & 8 & 6.66 & & \\
\hline & Medium & 103 & 85.83 & 11.33 & 2.039 \\
\hline & high & 9 & 7.5 & & \\
\hline \multirow[t]{4}{*}{7} & social participation & & & & \\
\hline & low & 23 & 19.16 & & \\
\hline & Medium & 73 & 60.83 & 26.19 & 3.776 \\
\hline & high & 24 & 20 & & \\
\hline \multirow[t]{4}{*}{8} & Sharing of responsibility & & & & \\
\hline & Low & 13 & 10.83 & & \\
\hline & Medium & 101 & 84.16 & 15.23 & 1.891 \\
\hline & high & 6 & 5 & & \\
\hline 9 & Innovativeness & & & & \\
\hline
\end{tabular}




\begin{tabular}{|c|c|c|c|c|c|}
\hline & low & 13 & 10.83 & & \\
\hline & medium & 104 & 86.66 & 20.10 & 2.364 \\
\hline & high & 3 & 2.5 & & \\
\hline \multirow[t]{4}{*}{10} & Attitude towards Panchayathiraj & & & & \\
\hline & low & 15 & 12.50 & & \\
\hline & medium & 95 & 79.16 & 48.77 & 5.83 \\
\hline & high & 10 & 8.33 & & \\
\hline \multirow[t]{4}{*}{11} & Leadership propensity & & & & \\
\hline & low & 12 & 10 & & \\
\hline & medium & 93 & 77.5 & 10.55 & 1.60 \\
\hline & high & 15 & 12.50 & & \\
\hline \multirow{4}{*}{12} & Attitude towards Participatory Planning & & & & \\
\hline & low & 16 & 13.30 & & \\
\hline & medium & 96 & 80 & 59.01 & 7.11 \\
\hline & high & 8 & 6.66 & & \\
\hline \multirow[t]{4}{*}{13} & Extension Agency Contact & & & & \\
\hline & low & 21 & 17.50 & & \\
\hline & medium & 79 & 65.83 & 27.93 & 3.839 \\
\hline & high & 20 & 16.66 & & \\
\hline \multirow[t]{4}{*}{14} & $\begin{array}{c}\text { Accountability in planning and } \\
\text { implementation }\end{array}$ & & & & \\
\hline & low & 28 & 23.33 & & \\
\hline & medium & 79 & 65.83 & 7.39 & 1.17 \\
\hline & high & 13 & 10.83 & & \\
\hline \multirow[t]{4}{*}{15} & Transparency within the group & & & & \\
\hline & low & 18 & 15 & & \\
\hline & medium & 86 & 71.67 & 6.52 & 1.01 \\
\hline & high & 16 & 13.33 & & \\
\hline \multirow[t]{4}{*}{16} & Sense of empowerment & & & & \\
\hline & low & 15 & 12.5 & & \\
\hline & medium & 89 & 74.16 & 61.58 & 8.38 \\
\hline & high & 16 & 13.33 & & \\
\hline \multirow[t]{4}{*}{17} & Participation in working group & & & & \\
\hline & low & 27 & 22.50 & & \\
\hline & medium & 76 & 63.30 & 73.85 & 11.03 \\
\hline & high & 17 & 14.16 & & \\
\hline \multirow[t]{4}{*}{18} & Efficacy of decentralised planning & & & & \\
\hline & low & 21 & 17.50 & & \\
\hline & medium & 90 & 75.0 & 67.49 & 6.92 \\
\hline & high & 9 & 7.50 & & \\
\hline
\end{tabular}


Table.3 Distribution of Working Group members according to their overall Perceived Efficacy Index $(n=120)$

\begin{tabular}{|c|c|c|c|c|c|}
\hline SI No & Categories of OPEI & Number & Percentage & Mean & $\begin{array}{c}\text { Standard } \\
\text { deviation }\end{array}$ \\
\hline $\mathbf{1}$ & Low & 21 & 17.50 & & \\
\hline $\mathbf{2}$ & Medium & 90 & 75.0 & & 6.92 \\
\hline $\mathbf{3}$ & High & 9 & 7.50 & 67.49 & \\
\hline & Total & 120 & 100 & & \\
\hline
\end{tabular}

Table.4 Efficacy dimensions at different stages of Decentralised planning in agriculture

\begin{tabular}{|c|c|c|c|c|c|}
\hline Phases & Stages involved & $\begin{array}{c}\text { Efficacy } \\
\text { score } \\
\text { received }\end{array}$ & $\begin{array}{l}\text { Average } \\
\text { efficacy of } \\
\text { the phase }\end{array}$ & $\begin{array}{c}\text { Total } \\
\text { Perception } \\
\text { score }\end{array}$ & $\begin{array}{l}\text { Maximum } \\
\text { Score }\end{array}$ \\
\hline $\begin{array}{c}\text { Participatory } \\
\text { Need } \\
\text { assessment }\end{array}$ & $\begin{array}{l}\text { 1.Need identification } \\
\text { 2.Formation of working group } \\
\text { 3.Formation of Panchayath } \\
\text { planning committee PPC } \\
\text { 4. Holding of pre Gramasabha } \\
\text { consultations with stakeholders } \\
\text { 5. Holding of Gramasabha }\end{array}$ & $\begin{array}{l}14.63 \\
14.96 \\
11.73 \\
14.40 \\
15.16\end{array}$ & 14.17 & 70.88 & 100 \\
\hline $\begin{array}{c}\text { Plan } \\
\text { formulation } \\
\text { and resource } \\
\text { allocation } \\
\text { phase }\end{array}$ & $\begin{array}{l}\text { 1.Preparation of draft plan } \\
\text { proposals by the working group } \\
\text { 2.Discussion of draft plan in } \\
\text { development seminar } \\
\text { 3.Prioritization and resource } \\
\text { allocation by the local } \\
\text { governments } \\
\text { 4. Preparation of detailed } \\
\text { projects by the working group } \\
\text { 5. Finalization of annual plan by } \\
\text { the local government }\end{array}$ & $\begin{array}{l}15.20 \\
15.12 \\
12.36 \\
15.16 \\
11.08\end{array}$ & 13.78 & 68.92 & 100 \\
\hline $\begin{array}{c}\text { Plan appraisal, } \\
\text { Integration and } \\
\text { implementation } \\
\text { phase }\end{array}$ & $\begin{array}{l}\text { 1. Vetting of plan and technical } \\
\text { approval } \\
\text { 2.Approval of plans by the DPC } \\
\text { and issue of proceedings } \\
\text { 3. Consolidation of local body } \\
\text { plans to a district plan by the } \\
\text { DPC } \\
\text { 4. Plan implementation } \\
\text { 5. Integration of projects }\end{array}$ & $\begin{array}{c}14.28 \\
16.49 \\
11.62 \\
14.34 \\
9.04\end{array}$ & 13.15 & 65.77 & 100 \\
\hline
\end{tabular}


Table.5 Total Variance explained in factor analysis of variables of working group members with Perceived Efficacy of Decentralised planning

\begin{tabular}{|c|c|c|c|c|c|c|}
\hline \multirow{2}{*}{ Component } & \multicolumn{3}{|c|}{ Initial Eigen values } & \multicolumn{3}{c|}{ Rotation Sums of Squared Loadings } \\
\cline { 2 - 6 } & Total & \% of variance & Cumulative \% & Total & \% of variance & Cumulative \% \\
\hline $\mathbf{1}$ & 8.549 & 50.289 & 50.289 & 7.658 & 45.049 & 45.049 \\
\hline $\mathbf{2}$ & 1.870 & 11.002 & 61.291 & 2.148 & 12.633 & 57.681 \\
\hline $\mathbf{3}$ & 1.594 & 9.377 & 70.668 & 1.720 & 10.118 & 67.800 \\
\hline $\mathbf{4}$ & 1.114 & 6.552 & 77.220 & 1.601 & 9.421 & 77.220 \\
\hline $\mathbf{5}$ & .959 & 5.638 & 82.859 & & & \\
\hline $\mathbf{6}$ & .733 & 4.311 & 87.169 & & & \\
\hline $\mathbf{7}$ & .537 & 3.158 & 90.327 & & & \\
\hline $\mathbf{8}$ & .460 & 2.705 & 93.032 & & & \\
\hline $\mathbf{9}$ & .287 & 1.688 & 94.720 & & & \\
\hline $\mathbf{1 0}$ & .256 & 1.507 & 96.227 & & & \\
\hline $\mathbf{1 1}$ & .179 & 1.050 & 97.277 & & & \\
\hline $\mathbf{1 2}$ & .137 & .805 & 98.082 & & & \\
\hline $\mathbf{1 3}$ & .099 & .583 & 98.665 & & & \\
\hline $\mathbf{1 4}$ & .090 & .529 & 99.194 & & & \\
\hline $\mathbf{1 5}$ & .072 & .422 & 99.616 & & & \\
\hline $\mathbf{1 6}$ & .041 & .242 & 99.858 & & & \\
\hline $\mathbf{1 7}$ & .024 & .142 & 100.000 & & & \\
\hline Extraction Method: Principal Component Analysis & & & \\
\hline
\end{tabular}

Table.6 Factor loadings of items in perceived efficacy of Decentralised planning in Panchayats $(n=120)$

\begin{tabular}{|c|c|c|c|c|}
\hline $\begin{array}{l}\text { Factor } \\
\text { No }\end{array}$ & Items & Items extracted under factors & Factor loadings & Factor label \\
\hline \multicolumn{4}{|l|}{ Factor 1} & \multirow{11}{*}{$\begin{array}{l}\text { Development- } \\
\text { Participation } \\
\text { Inter dependence }\end{array}$} \\
\hline & 1 & Attitude towards Panchayati Raj & 0.915 & \\
\hline & 2 & Sharing of responsibility & 0.904 & \\
\hline & 3 & Extent of Participation in Working Groups & 0.904 & \\
\hline & 4 & Social Participation & 0.875 & \\
\hline & 5 & Attitude towards Participatory Planning & 0.856 & \\
\hline & 6 & Innovativeness & 0.847 & \\
\hline & 7 & Sense of Empowerment & 0.822 & \\
\hline & 8 & Extension agency contact & 0.821 & \\
\hline & 9 & Leadership Quality & 0.792 & \\
\hline & 10 & Mass media Exposure & 0.729 & \\
\hline \multirow[t]{2}{*}{ Factor 2} & & Transparency within the group & 0.726 & \multirow{2}{*}{$\begin{array}{l}\text { Group Decision } \\
\text { making \& } \\
\text { performance }\end{array}$} \\
\hline & & Land Size & -0.677 & \\
\hline \multirow[t]{3}{*}{ Factor 3} & & Age & 0.880 & \multirow{3}{*}{$\begin{array}{c}\text { Experience - } \\
\text { Accountability } \\
\text { capabilities }\end{array}$} \\
\hline & & $\begin{array}{l}\text { Accountability in Planning and } \\
\text { Implementation }\end{array}$ & 0.655 & \\
\hline & & Experience in farming & 0.565 & \\
\hline \multirow[t]{2}{*}{ Factor 4} & & Education & 0.853 & \multirow[b]{2}{*}{$\begin{array}{l}\text { Knowledge } \\
\text { mediation }\end{array}$} \\
\hline & & Leadership Propensity & 0.558 & \\
\hline
\end{tabular}


Fig.1 Stages of Decentralized Agricultural Planning Through Local Self Government Institutions LSGIs

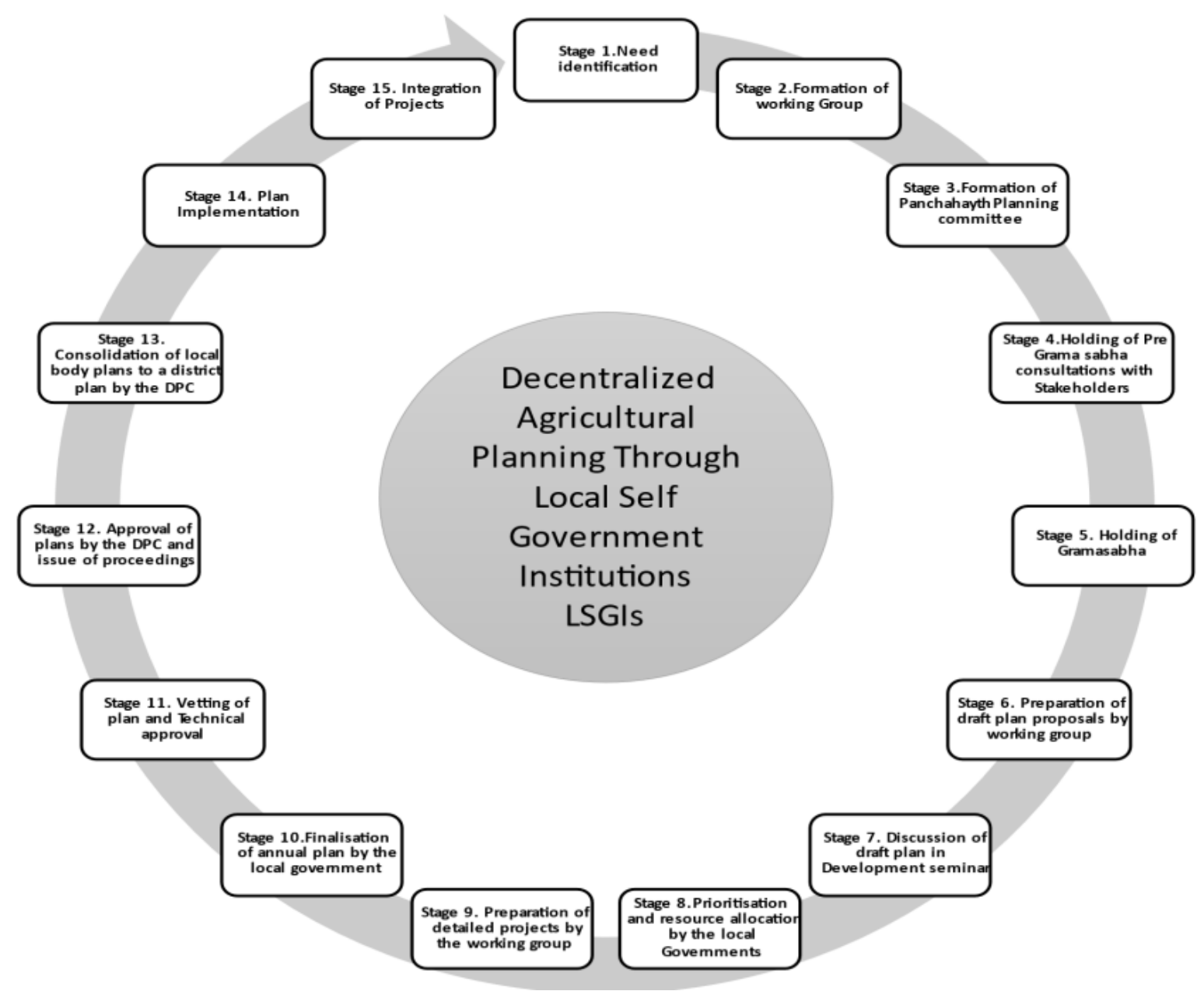

Fig.2 Distribution of Respondents according to their PEDP

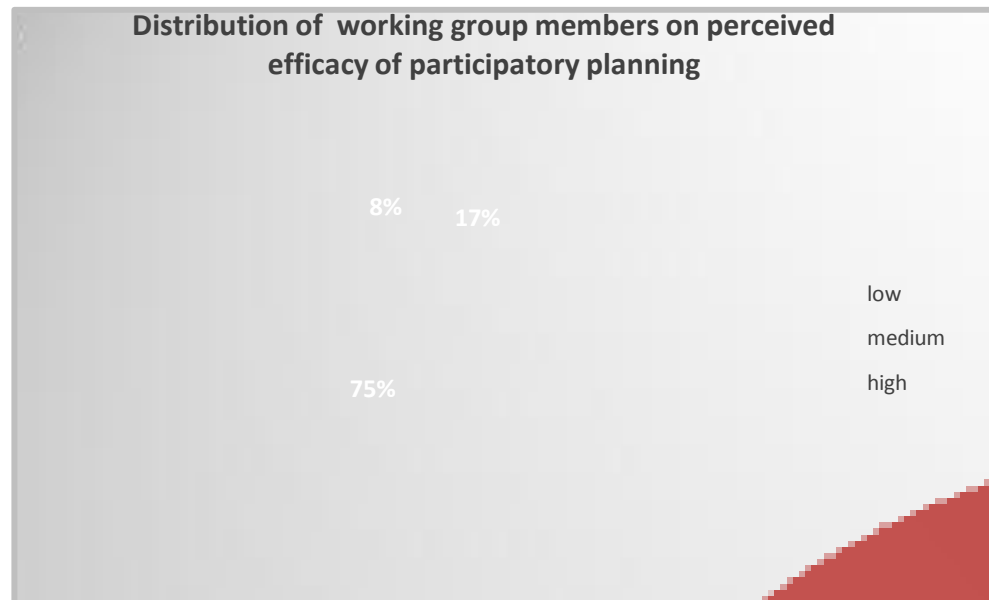


Fig.3 Factor scree plot of determinants of perceived efficacy of working group members in decentralized planning in LSGIs of Kerala

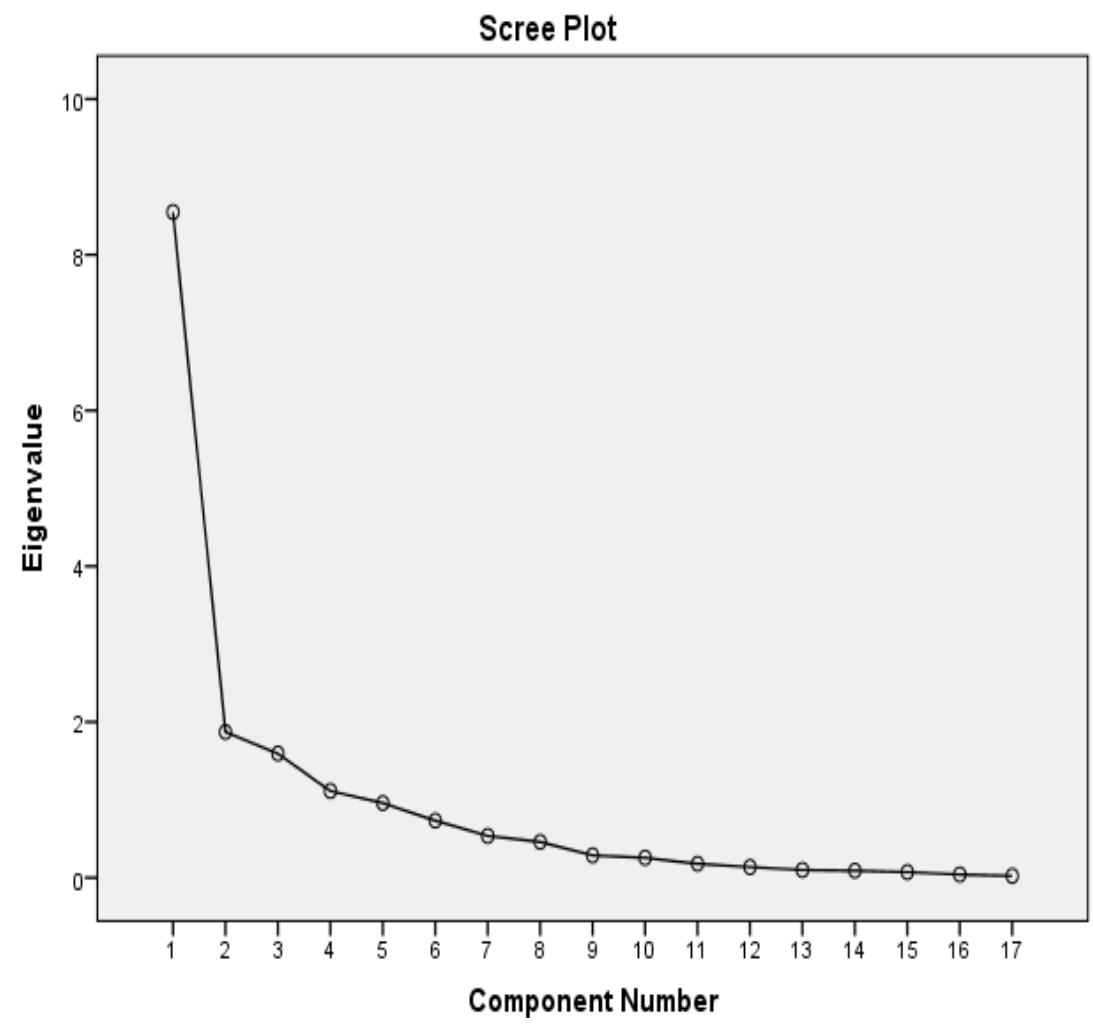

Fig.4 Diagrammatic representation of delineated factors affecting perceived efficacy of decentralized planning by working group members of LSGIs

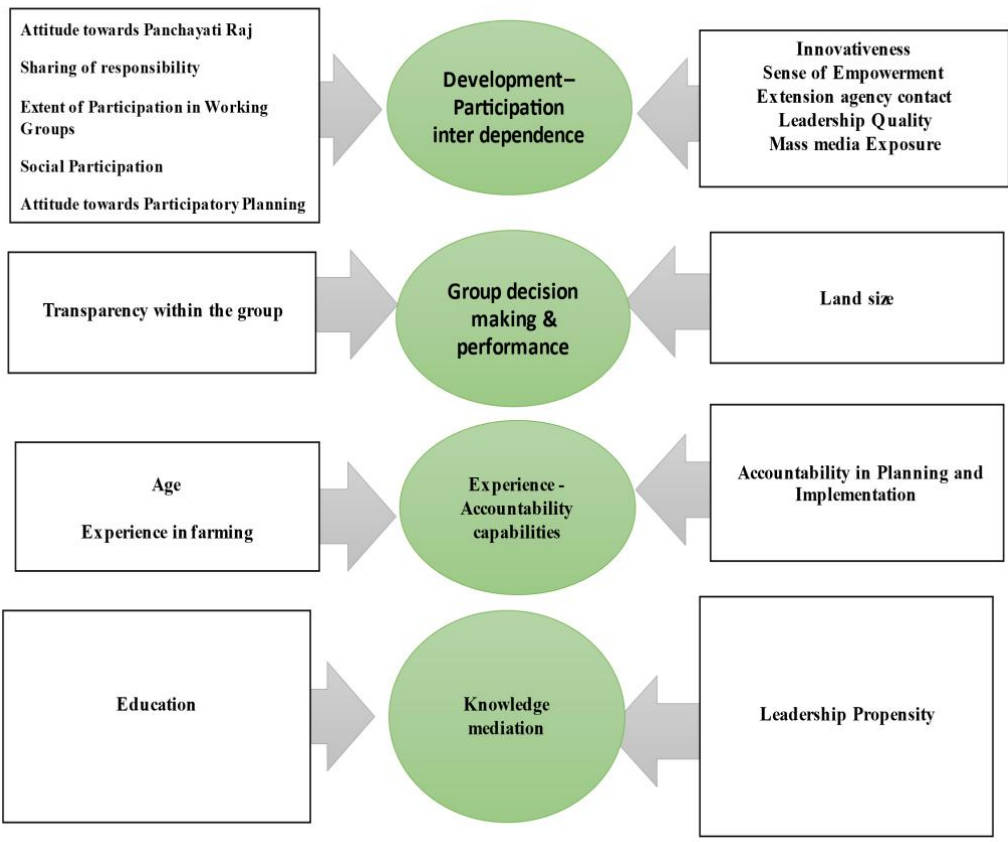


Out of the three phases, plan appraisal, integration and implementation phase had the least perceived efficacy, followed by the plan formulation and resource allocation phase. Among the stages, integration of projects had the lowest efficacy perception score followed by finalization of annual plan by the local government, consolidation of local body plans to a district plan by the DPC and formation of Panchayath planning committee PPC, explaining that the efficacy of these dimensions needs to be improved. Dimensions having high scores were approval of plans by the DPC, preparation of detailed projects by the working group, holding of Gramasabha, preparation of draft plan proposals and discussion in the development seminar.

\section{Determinants of Perceived Efficacy by Working group members}

Factor analysis through PCA thus helped to reduce the influence of variables to a few variables. The result of the factor analysis has been discussed in Table.5.

It can be seen from the above table that out of the 14 variables, four factors could explain $77 \%$ variance in the perceived efficacy. Components with Eigen values greater than one were only selected.

Rotation maximized the loading of the variable on one of the extracted factors while minimizing the loading in other factors. Scree plot depicting the delineated factors on the $\mathrm{X}$ axis and the corresponding Eigen values on the $\mathrm{Y}$ axis was used to extract the major determining factors (Figure.3).

The extracted graph flattened off after the break of the inflexion and the four factors before the point were selected as the major determining factors. The major factors together explained 77.22 per cent of total variance. The results of the rotated factor matrix for the items covered under each factor have been presented in Table.6.

Factor analysis delineated four factors that affected the efficacy perception of the working group members of selected Panchayats. It was observed that these factors had significant influence on the perception of the efficacy and are independent of each other. Each factor was derived from a weighted linear combination of variables that accounted for the largest total variation in the data.

These factors are given in the order of importance with respect to the proportion of the variance accounted by each factor. These four factors together explained a total variance of 77.22 per cent which implied high significance of the selected variables in the efficacy of institutionalization of decentralized planning in agriculture in Village Panchayats of Kerala.

The results showed that Factor 1 comprised of 10 items with factor loadings ranging from 0.729 to 0.915 . It also showed that Factor 2 had two factors with factor loadings ranging from 0.67 to 0.73 , while Factor 3 had three items with factor loadings ranging of 0.880 to 0.655. Factor 4 had two items with factor loadings of 0.85 and 0.56 . The uniformly high values of factor loadings indicated the significance of these variables in the delineated factors and the overall efficacy perception. Based on the items loaded under each factor, appropriate nomenclature was assigned and has been depicted as major factors in Fig.4.

Accordingly, the major factors that have close relationship with the efficacy perception were identified as Development-Participation Inter dependence, Group Decision making \& performance, Experience - Accountability capabilities, and Knowledge mediation. The Development-Participation Inter dependence 
factor alone could explain $45.05 \%$ total variance.

\section{References}

GoK [Government of Kerala]. 2017. Thirteenth five-year plan 2017-22, Approach paper, State Planning Board, Thiruvananthapuram, 72p.

Heller, P., Harilal, K. N. and Chaudhuri, S., 2007. Building local democracy: Evaluating the impact of decentralization in Kerala, India. World development,35(4), pp.626-648.

Vijayanand (2010) Vijayanand S M. 2010, Decentralisation : A Decade of Kerala Experience, Kerala Institute of Local Governance (KILA). $44 \mathrm{p}$

Alex, J. P. and Sulaja, O. R. 2012. Knowledge management for participatory planning at the grassroots: dimensions, prospects and issues, Indian Res. J. Ext. Educ. 12 (1): 87-93.

Harilal, K. N. 2012. Planning as an instrument of plotics- Rethinking the methodology of local level participatory planning in Kerala, Occasional Paper, 2012:1,Centre for development Studies, Thiruvananthapuram 41p.

Jabbar, P. K. A. and Sundaramari, A. 2014. Perceived effectiveness of farmer participatory planning in Kerala. KILA J. Local Governance1 (1): 31-36.

Mohanan Pillai, P and Prakash, C. 2016. Social Classes and Participation in Local Planning in Kerala : A Micro Level Study, RULSG Occasional Paper 2016 : 1,Research Unit On Local Self Governments, Centre For Development Studies, Thiruvananthapuram.19p

Dominic D M and Gupta J. 2019. Institutionalization of dairy innovation platforms: A study on Samagra project in Kerala, Indian J Dairy Sci. 72(5): 542-546

Shrivastava. P, Shrivastava, K. K and Anupama V. 2021. Contribution of Characteristics of Panchayat Leaders towards their Attitude as Evident from the Multiple Regression Analysis. Indian Journal of Extension Education Vol. 57, No. 1 (January-March), 2021, (73-77).

\section{How to cite this article:}

Abdul Jabbar, P. K. and Jiju P. Alex. 2021. Decentralized Agricultural Planning in KeralaProcess and Determinants of Efficacy. Int.J.Curr.Microbiol.App.Sci. 10(12): 404-415. doi: https://doi.org/10.20546/ijcmas.2021.1012.045 